\title{
Product Name Code Modified Text
}

National Cancer Institute

\section{Source}

National Cancer Institute. Product Name Code Modified Text. NCI Thesaurus. Code C94026.

A character string that is a revision of the original text of the product to enable the coding of the text. 